\title{
A METODOLOGIA NA PESQUISA EM JORNALISMO DIGITAL DO SUL DO BRASIL
}

\author{
Methodology in research on digital Journalism of the South Brazil \\ Metodología de investigación en periodismo digital del Sur de Brazil
}

\author{
Claudia Irene de Quadros \\ Universidade Federal do Paraná \\ clauquadros@gmail.com
}

Mônica Cristine Fort Universidade Tuiuti do Paraná monicacfort@gmail.com

Mônica Panis Kaseker Universidade Estadual de Londrina mkaseker@gmail.com

\begin{abstract}
Resumo
O artigo destaca as metodologias das teses de doutorado defendidas, entre 2006 e 2018, em seis Programas de Pós-graduação em Comunicação da região Sul do Brasil. Na primeira etapa desta pesquisa, fizemos um mapeamento das metodologias utilizadas nos estudos em jornalismo digital. Na segunda etapa, buscamos nos repositórios das próprias instituições citadas as teses listadas nas bases de dados da Capes. As teses foram analisadas a partir de uma ficha elaborada para verificar qual abordagem teórico-metodológica adotada, quais as principais matrizes teóricas e se apresenta uma metodologia própria para o objeto investigado. Conclui-se que as teses da região Sul adotam perspectivas multidisciplinares e desenhos teórico-metodológicos complexos para adaptar-se aos objetos de estudo do jornalismo em contexto de convergência.
\end{abstract}

Palavras-chave: Jornalismo Digital. Estado da arte. Metodologias.

\begin{abstract}
The article emphasizes the methodologies of doctoral theses defended in six Post-graduate Programs in Communication of the South region between 2006 and 2018. In the first stage of this research, which aims to review the methodologies used in studies in digital journalism, we surveyed Capes databases. In the second stage, we search the repositories of the cited institutions for the theses listed in the Capes databases. The theses were analyzed based on a form elaborated to verify which theoretical-methodological approach was adopted, which are the main theoretical matrices and presents a proper methodology for the investigated object. It is concluded that the theses of the South region adopt multidisciplinary perspectives and complex theoretical-
\end{abstract}


methodological designs to adapt to the objects of study of journalism in a context of convergence.

Keywords: Digital Journalism. State of art. Methodologies.

\section{Resumen}

El artículo destaca las metodologías de tesis doctorales defendidas, entre 2006 y 2018, en seis Programas de Postgrado en Comunicación de la región Sur. En la primera etapa de esta investigación, cuyo objetivo es revisar las metodologías utilizadas en los estudios de periodismo digital, examinamos en las bases de datos de la Capes. En la segunda etapa, buscamos en los repositorios de las instituciones citadas las tesis que figuran en las bases de datos de la Capes. Las tesis fueron analizadas basándose en una forma elaborada para verificar qué enfoque teórico-metodológico se adoptó, cuáles son las matrices teóricas principales y se presenta una metodología adecuada para el objeto investigado. Se concluye que las tesis de la región sur adoptan perspectivas multidisciplinares y diseños teórico-metodológicos complejos para adaptarse a los objetos de estudio del periodismo en un contexto de convergencia.

Palabras clave: Periodismo digital. Estado del arte. Metodologías

\section{DIRETRIZES PARA O MAPEAMENTO DE METODOLOGIAS}

A preocupação em acompanhar os estudos em jornalismo digital não é nova (QUADROS; MIELNICZUK; BARBOSA, 2006), mas nem por isso deixa de ser essencial. Os caminhos traçados pelos pesquisadores da área devem ser revisitados para refletirmos sobre a pesquisa em qualquer campo. Neste estudo, procuramos fazer um mapeamento das metodologias utilizadas nos estudos em jornalismo digital das teses defendidas entre 2006 a 2018 em seis Programas de Pós-graduação em Comunicação da região Sul do Brasil: PUC-RS, UNISINOS, UFRGS, UFSM, UTP e UFSC. O curso de doutorado da UFPR, aprovado em 2018, ainda não possui teses defendidas no período e, por isso, não faz parte do corpus desta pesquisa. Na primeira etapa, fizemos o levantamento no banco de teses da Capes (2006 a 2012) e na plataforma Sucupira (2013 a 2018) com o apoio de pesquisadores que integram os grupos de pesquisa COM XXI e INCOM ${ }^{1}$. Na segunda etapa, buscamos nos repositórios das próprias instituições citadas as teses listadas nas referidas bases de dados da Coordenação de Aperfeiçoamento de Pessoal de Nível Superior (CAPES) sobre o tema. As 43 teses encontradas foram analisadas a partir de uma ficha elaborada para verificar qual abordagem teórico-

\footnotetext{
${ }^{1}$ O COMXXI funciona na UFPR e o INCOM na UTP. Ambos estão associados aos seus respectivos Programas de Pós-graduação em Comunicação.
} 
metodológica adotada, quais as principais matrizes teóricas, os autores mais citados e se a tese apresenta uma metodologia própria para o objeto investigado.

Os resultados aqui apresentados fazem parte de dois projetos de pesquisa: (a) "Mapeamento das pesquisas em comunicação digital" e (b) "Das práticas inovadoras e criativas no jornalismo em redes digitais às suas formas de abordagem pelo pensamento acadêmico". O primeiro deles é desenvolvido por docentes do Programa de Pós-graduação em Comunicação da COM XXI². O segundo faz parte de um convênio firmado em 2013 entre a UFPR e a Universidade de Lyon II para estudar "Novas práticas jornalísticas", que envolve pesquisadores brasileiros e franceses. Com a coordenação no Brasil do PPGCOM-UFPR, o projeto conta com a participação de duas instituições de Curitiba convidadas: Universidade Tuiuti do Paraná - UTP e Universidade Positivo - UP. Em 2016, a partir do desenvolvimento do projeto b, sob a responsabilidade da professora Kati Caetano, do programa em Comunicação e Linguagens da UTP, pesquisadores de outras instituições (UEPG, UEL, UFBA, UFOP e UEPB) e da própria UFPR passaram a fazer parte dele. A associação entre pesquisadores, projetos e instituições também possibilitou a ampliação das questões da ficha para observar as teses e dissertações em jornalismo digital defendidas no Brasil, como a busca por pesquisas que investigam propostas inovadoras/criativas no jornalismo em redes digitais e quais são essas práticas.

O mapeamento das pesquisas em jornalismo digital é fundamental para estabelecer diálogo com outros investigadores e, assim, ter ideias para realizar novos trabalhos científicos. Para Ana Carolina D. Escosteguy (2008) esse é o tipo de investigação essencial para o avanço da pesquisa.

\footnotetext{
Esse tipo de documentação - seja descritiva ou interpretativa na medida em que avalie as abordagens teórico-metodológicas e os resultados das investigações inventariadas - é essencial para que a pesquisa avance, pois é através dela que são detectados os consensos e as lacunas, os avanços e as deficiências sobre a problemática em tela. Não é a familiaridade com o estado do conhecimento sobre um tema dentro de uma área o que torna o pesquisador capaz de problematizá-lo? (ESCOSTEGUY, 2008, p. 8).
}

Ainda que no campo da comunicação este tipo de pesquisa não seja tão valorizado (ESCOSTEGUY, 2008), em outras áreas do conhecimento tem sido cada vez mais explorado (FERREIRA, 2002). A pesquisadora Norma Sandra de Almeida Ferreira (2002) descreve dois tipos de pesquisa do estado da arte de uma área. O primeiro deles procura identificar e quantificar a produção científica de um determinado período, local e áreas do conhecimento. A

${ }^{2}$ O COM XXI, Comunicação para o século XXI, conta com pesquisadores de outros setores da UFPR e de outras instituições: UEL, UEPG e UnB. As duas líderes do grupo são docentes da UFPR e da UEPG. 
produção é ordenada para perceber a evolução do campo e os locais de produção. No segundo tipo de pesquisa, é possível inventariar a produção científica ao refletir sobre escolhas teóricometodológicas e tendências.

Esta pesquisa trata, portanto, sobre metodologias utilizadas nas teses de doutorado em jornalismo digital defendidas nos programas de pós-graduação em Comunicação do Brasil, no período de 2006 a 2016. Neste artigo, o recorte temporal foi atualizado e ampliado a 2018, mas o local ficou restringido à região Sul do país. As bases de dados da Capes e os repositórios dos programas de pós-graduação brasileiros facilitaram a pesquisa, mas para estudar as metodologias utilizadas foi necessário ir além dos resumos. Nosso olhar concentrou-se nas escolhas teóricometodológicas dessas teses. Para tanto, além da análise guiada pela ficha de avaliação (ver no apêndice deste artigo), traçamos um breve perfil dos programas de doutorado em Comunicação da região na primeira etapa da pesquisa.

\section{PERFIL DE PROGRAMAS EM COMUNICAÇÃO}

A área de Comunicação e Informação possui 56 Programas de Pós-graduação em Comunicação registrados, em julho de 2019, na Plataforma Sucupira ${ }^{3}$. Destes, 32 também apresentam cursos de doutorado. Oito novos cursos de doutorado foram aprovados em 2018 pela Capes. Na região Sul, há sete programas com mestrado e doutorado, quatro de universidades públicas e três de universidades privadas. Na tabela 1, destacamos o ano de criação do doutorado. Na última avaliação da Capes, em 2017, três Programas subiram de nota: PUC-RS, UTP e UFPR, o que permitiu a criação do doutorado desta última instituição que não será analisada neste artigo.

Tabela 1 - Programas de Pós-graduação em Comunicação com mestrado e doutorado

\begin{tabular}{|l|l|l|l|l|}
\hline ESTADO & INSTITUIÇÃO & PROGRAMA & ANO & NOTA \\
\hline RS & PUC-RS & Comunicação Social & 1999 & 5 \\
\hline RS & UNISINOS & Ciências da Comunicação & 1999 & 6 \\
\hline RS & UFRGS & $\begin{array}{l}\text { Comunicação e } \\
\text { Informação }\end{array}$ & 2000 & 5 \\
\hline
\end{tabular}

\footnotetext{
${ }^{3}$ Os cursos reconhecidos podem ser visualizados na Plataforma Sucupira. Disponível em https://goo.gl/2JrFkp. Acesso em 16 de julho de 2019.
} 


\begin{tabular}{|l|l|l|l|l|}
\hline PR & UTP & $\begin{array}{l}\text { Comunicação e } \\
\text { Linguagens }\end{array}$ & 2010 & 5 \\
\hline RS & UFSM & Comunicação & 2012 & 5 \\
\hline SC & UFSC & Jornalismo & 2014 & 4 \\
\hline PR & UFPR & Comunicação & 2018 & 4 \\
\hline
\end{tabular}

Fonte: Plataforma Sucupira, 2019.

A região Sul conta ainda com dois cursos de mestrado acadêmico e um profissional. Para apresentar um projeto de curso de doutorado, um programa de pós-graduação stricto sensu precisa obter a nota 4 na avaliação da Capes. Os programas da tabela 2 obtiveram nota 3 na avaliação realizada em 2017.

Tabela 2 - Programas de Pós-graduação em Comunicação com mestrado

\begin{tabular}{|c|c|c|c|c|}
\hline \multicolumn{5}{|c|}{ Mestrado Acadêmico } \\
\hline Estado & Instituição & Programa & Ano & Nota \\
\hline PR & UEL & Comunicação & 2008 & 3 \\
\hline PR & UEPG & Jornalismo & 2012 & 3 \\
\hline \multicolumn{5}{|c|}{ Mestrado Profissional } \\
\hline Estado & Instituição & Programa & Ano & Nota \\
\hline RS & UNIPAMPA & $\begin{array}{l}\text { Comunicação e Indústria } \\
\text { criativa }\end{array}$ & 2016 & 3 \\
\hline
\end{tabular}

Fonte: Plataforma Sucupira, 2019 .

Os programas de pós-graduação em comunicação da região Sul são recentes quando comparados com os da região Sudeste, que teve os primeiros cursos de doutorado no início da década de 80. Antes da análise das teses de doutorado defendidas em programas de pósgraduação em comunicação da PUC-RS, da UNISINOS, da UFRGS, da UFSM, da UTP e da UFSC, apresentamos um breve perfil de cada um deles. É importante destacar que na coleta de 2017 registramos as linhas de pesquisa apresentadas no site do programa. Nem todas as teses trazem o vínculo das linhas de pesquisa, o que dificulta acompanhar a evolução de cada uma delas. Para isso, é preciso consultar as avaliações realizadas pela Capes de cada programa de pós-graduação. Na coleta de 2019, três programas sofreram ajustes em suas linhas de pesquisa. 
O mestrado do Programa de Pós-Graduação em Comunicação Social da PUC-RS foi recomendado pela Capes em 1994, quatro anos depois, o doutorado. A área de concentração está focalizada nos Estudos das Práticas e Culturas da Comunicação. No momento da coleta de pesquisa possuía duas linhas de pesquisa: (a) Práticas Culturais nas Mídias, Comportamentos e Imaginários da Sociedade da Comunicação e (b) Práticas Profissionais e Processos Sociopolíticos nas Mídias e na Comunicação das Organizações. Em 2019, encontramos ajustes em ambas as linhas, que passaram a ser assim denominadas: (a) Cultural e Tecnologias das Imagens e dos Imaginários e (b) Política e Práticas Profissionais na Comunicação. Das 182 teses, 10 foram classificadas neste estudo como de jornalismo digital como mostra a tabela 3.

Tabela 3 - Quantidade de teses de doutorado do Programa em Comunicação Social da PUC-RS

\begin{tabular}{|c|c|c|}
\hline ANO DE DEFESA & TOTAL DE DEFESAS & SOBRE JORNALISMO DIGITAL \\
\hline 2018 & 11 & 2 \\
\hline 2017 & 14 & 1 \\
\hline 2016 & 26 & 0 \\
\hline 2015 & 11 & 2 \\
\hline 2014 & 13 & 0 \\
\hline 2013 & 11 & 0 \\
\hline 2012 & 7 & 0 \\
\hline 2011 & 13 & 1 \\
\hline 2010 & 18 & 0 \\
\hline 2009 & 5 & 0 \\
\hline 2008 & 17 & 1 \\
\hline 2007 & 27 & 10 \\
\hline 2006 & 9 & 2019 \\
\hline TOTAL & 182 & 2 \\
\hline
\end{tabular}

Fonte: Repositório da PUC-RS e da Plataforma Sucupira, 2019.

O mestrado do Programa de Pós-Graduação em Ciências da Comunicação da Universidade do Vale dos Sinos - Unisinos foi reconhecido pela Capes em 1994 e o doutorado, em 1999, cuja área de concentração é em Processos Midiáticos. Possui quatro linhas de pesquisa: (a) Mídias e Processos Audiovisuais, (b) Linguagens e Práticas Jornalísticas, (c) Cultura, Cidadania e Tecnologias da Comunicação e (d) Midiatização e Processos Sociais. Nos treze anos analisados, foram defendidas 145 teses de doutorado, destas, 13 são em jornalismo digital, conforme aponta a tabela 4. 
Tabela 4 - Quantidade de teses de doutorado do Programa em Ciências da Comunicação da Unisinos

\begin{tabular}{|c|c|c|}
\hline ANO DE DEFESA & TOTAL DE DEFESAS & SOBRE JORNALISMO DIGITAL \\
\hline 2018 & 12 & 3 \\
\hline 2017 & 13 & 2 \\
\hline 2016 & 10 & 2 \\
\hline 2015 & 11 & 2 \\
\hline 2014 & 18 & 0 \\
\hline 2013 & 13 & 1 \\
\hline 2012 & 11 & 0 \\
\hline 2011 & 9 & 0 \\
\hline 2010 & 8 & 0 \\
\hline 2009 & 9 & 0 \\
\hline 2008 & 11 & 0 \\
\hline 2007 & 9 & 13 \\
\hline 2006 & 11 & 1 \\
\hline TOTAL & 145 & 2019. \\
\hline
\end{tabular}

Fonte: Repositório da Unisinos e da Plataforma Sucupira, 2019.

O Programa em Comunicação e Informação da Universidade Federal do Rio Grande do Sul - UFRGS teve o mestrado reconhecido em 1995 e o doutorado foi implantado em 2001. Sua área de concentração é a Comunicação e Informação, por isso se apresenta como um programa com característica interdisciplinar desde sua origem. Suas linhas de pesquisa foram alteradas após a avaliação quadrienal. O programa da UFRGS apresenta em 2019 duas novas linhas de Pesquisa: (a) Redes Sociais, Interações e Sociabilidades e (b) Culturas, Políticas e Significação. Durante a coleta dos dados o programa mantinha quatro linhas de pesquisa: (a) Informação, Redes Sociais e Tecnologias, (b) Jornalismo e Processos Editoriais, (c) Cultura e Significação, (d) Mediações e Representações Culturais e Políticas. Das 107 teses defendidas, apenas onze podem ser classificadas como de jornalismo digital, como apresentado na tabela 5.

Tabela 5 - Quantidade de teses de doutorado do Programa em Comunicação e Informação da UFRGS

\begin{tabular}{|c|c|c|}
\hline ANO DE DEFESA & TOTAL DE DEFESAS & SOBRE JORNALISMO DIGITAL \\
\hline 2018 & 16 & 3 \\
\hline 2017 & 19 & 3 \\
\hline 2016 & 17 & 0 \\
\hline 2015 & 12 & 2 \\
\hline 2014 & 11 & 0 \\
\hline 2013 & 7 & 1 \\
\hline 2012 & 7 & 0 \\
\hline 2011 & 8 & 0 \\
\hline 2010 & 0 & 1 \\
\hline 2009 & 6 & \\
\hline
\end{tabular}




\begin{tabular}{|c|c|c|}
\hline 2008 & 1 & 0 \\
\hline 2007 & 3 & 0 \\
\hline TOTAL & 107 & 11 \\
\hline
\end{tabular}

Fonte: Repositório da UFRGS e da Plataforma Sucupira, 2019.

O Programa em Comunicação da Universidade Federal de Santa Maria - UFSM conseguiu a aprovação da Capes para o mestrado em 2006 e para o doutorado em 2012. A área de concentração foi definida em Comunicação Midiática, apresentando duas linhas de pesquisa: (a) Mídias e Identidades Contemporâneas e (b) Mídias e Estratégias Comunicacionais. Das 33 teses defendidas no período de análise (2006-2018), três tratam do jornalismo digital como demonstrado na tabela 6 .

Tabela 6 - Quantidade de teses de doutorado do Programa em Comunicação da UFSM

\begin{tabular}{|c|c|c|}
\hline & & \\
ANO DE DEFESA & TOTAL DE DEFESAS & SOBRE JORNALISMO DIGITAL \\
\hline 2018 & 15 & 1 \\
\hline 2017 & 12 & 0 \\
\hline 2016 & 6 & 1 \\
\hline 2015 & 5 & 1 \\
\hline TOTAL & 38 & 3 \\
\hline
\end{tabular}

Fonte: Repositório da UFSM e da Plataforma Sucupira, 2019.

O Programa de Pós-Graduação em Comunicação e Linguagens da Universidade Tuiuti do Paraná - UTP teve o mestrado aprovado em 1999 e o doutorado em 2010, cuja área de concentração está nos estudos de Processos Comunicacionais. Possui duas linhas de pesquisa: (a) Estudos de Cinema e Audiovisual e (b) Processos Mediáticos e Práticas Comunicacionais. As primeiras teses começaram a ser defendidas em 2013, desde então foram 34 investigações concluídas até 2018. Destas, somente quatro estão focadas no jornalismo digital, conforme apontado na tabela 7 .

Tabela 7 - Quantidade de teses de doutorado do Programa em Comunicação e Linguagens da UTP

\begin{tabular}{|c|c|c|}
\hline ANO DE DEFESA & TOTAL DE DEFESAS & SOBRE JORNALISMO DIGITAL \\
\hline 2018 & 12 & 1 \\
\hline 2017 & 4 & 0 \\
\hline 2016 & 8 & 1 \\
\hline 2015 & 5 & 1 \\
\hline 2014 & 3 & 0 \\
\hline 2013 & 2 & 4 \\
\hline TOTAL & 34 & 2019. \\
\hline
\end{tabular}

Fonte: Repositório da UTP e da Plataforma Sucupira, 2019. 
Na Universidade Federal de Santa Catarina, o Programa de Pós-Graduação em Jornalismo iniciou com o mestrado em 2007. O doutorado teve início em 2014, com duas linhas de pesquisa: (a) Jornalismo, Cultura e Sociedade e Tecnologias, Linguagens e (b) Inovação no Jornalismo. Até 2018, foram defendidas quatro teses, sendo duas em jornalismo digital, como demonstrado na tabela 8 .

Tabela 8 - Quantidade de teses de doutorado do Programa em Jornalismo da UFSC

\begin{tabular}{|c|c|c|}
\hline ANO DE DEFESA & TOTAL DE DEFESAS & SOBRE JORNALISMO DIGITAL \\
\hline 2018 & 3 & 1 \\
\hline 2017 & 1 & 1 \\
\hline TOTAL & 4 & 2 \\
\hline
\end{tabular}

Fonte: Repositório da UFSC e da Plataforma Sucupira, 2019.

\section{AS TESES EM JORNALISMO DIGITAL E METODOLOGIAS}

As discussões sobre a terminologia mais apropriada para classificar os estudos sobre o jornalismo produzido na internet têm mais de duas décadas. Ao longo desses anos, foram adotados diversos termos, como jornalismo on-line, jornalismo digital, webjornalismo e ciberjornalismo (CANAVILHAS, 1999; MACHADO, 2000; MIELNICZUK, 2003). No presente trabalho, adotamos o termo jornalismo digital. No Brasil, em 2010, um projeto apoiado pelo Itaú Cultural reuniu pesquisadores considerados pioneiros no campo para discutir sobre tendências, avanços, ensino, teorias e conceitos. Na época, a maioria já adotava o termo jornalismo digital por ser mais amplo, para facilitar a indexação dos resultados da pesquisa e, principalmente, por implicar em questões conceituais que apontavam a sua transformação. A discussão completa deste grupo pode ser encontrada no capítulo 5 do livro "Mapeamento 2: do ensino de jornalismo digital no Brasil em 2010, organizado por Alex Primo (2010).

Dez anos depois, em 2019, a Digital Journalism lançou uma edição especial sobre as definições deste campo, principalmente de seu conceito-chave: o jornalismo digital. No editorial desta revista científica, Scott A. Eldridge II et al. (2019) destaca a importância entre preservar o tradicional e abrir os olhos para o novo para avançar nos estudos do jornalismo digital. Tal reflexão surge a partir dos termos utilizados nas pesquisas deste campo, pois, muitas vezes como apontam Steensen et. al. (2019), conceitos são introduzidos por alguns investigadores que raramente serão usados por outros. Também é comum encontrar novas perspectivas para observar o jornalismo digital sem considerar o que já foi produzido sobre o assunto. Autores 
desse dossiê, como Barbie Zelizer, mostram que o termo digital vai além da tecnologia. A pesquisadora argumenta que o digital não é um ambiente, mas uma modalidade que serve para acompanhar as mudanças, as estruturas, as práticas e os valores do jornalismo. Também faz uma crítica aos estudos de jornalismo digital, solicitando menos fixação pela novidade e um pouco mais de história para compreender as suas transformações.

Nas teses analisadas nesta etapa da pesquisa, também encontramos outras denominações, como jornalismo em redes digitais, jornalismo em dispositivos móveis e jornalismo em base de dados. No período analisado (2006-2018) cresce o número de investigações interessadas em compreender as transformações do jornalismo em contexto de convergência. Os estudos exploram práticas produtivas do jornalismo digital, linguagens, circulação e, cada vez mais, interações entre produtores e leitores.

Neste artigo, o nosso objetivo é analisar as metodologias das teses de doutorado em comunicação dos programas de pós-graduação da região Sul que estudam o jornalismo digital. Ao abordar as opções metodológicas das teses analisadas, estamos certamente nos referindo às matrizes geradoras dessas estratégias. Como destacam Lago e Benetti (2010, p. 17), as pesquisas do campo jornalístico são marcadas pela multidimensionalidade, seus objetos de estudo são, com frequência, multidisciplinares e utilizam metodologias formatadas em outras disciplinas.

É exatamente esta junção e articulação de diferentes disciplinas, com seus próprios pressupostos, que obriga a um aprofundamento não só a respeito dos paradigmas próprios do que se pretende articular, mas também sobre as diferentes respostas metodológicas produzidas historicamente em referência a esses parâmetros. E, se essa premissa é verdadeira, é fato que muitas vezes não é acompanhada de uma práxis rigorosa, resultando em pesquisas com baixo nível de explicitação das estratégias metodológicas, além da insipiência do discurso sobre o método. (LAGO; BENETTI, 2010, p. 18).

A maioria das pesquisas analisadas fez abordagens metodológicas qualitativas, que de acordo com Fragoso, Recuero e Amaral (2015, p. 67) “visa uma compreensão e holística dos fenômenos em estudo e, para tanto, os contextualiza e reconhece seu caráter dinâmico”. Nesse sentido, percebemos que as escolhas dos elementos analisados e de suas amostras foram feitas de acordo com o problema de pesquisa, das características do universo observado e das condições e métodos de observação e análise.

No Programa de Pós-graduação em Comunicação da PUC-RS, as dez teses analisadas, destacadas no quadro 1, foram orientadas por oito professores. Destes, seis têm formação em jornalismo e três em publicidade. De caráter qualitativo, as investigações científicas adotam múltiplos métodos, incorporados de outras pesquisas, sempre adaptados aos objetos de estudo 
propostos. As teses revisitam conceitos clássicos do jornalismo, como newsmaking e critérios de noticiabilidade, para compreender as novas práticas da profissão em contexto de convergência. Desde o boom do jornalismo digital, em 1995, a rotina do trabalho jornalístico mudou muito. As teses defendidas na PUC-RS mostram essas transformações em objetos empíricos locais, nacionais e internacionais. E, aquelas defendidas nos últimos três anos, abordam preocupações com fenômenos que surgem com as redes sociais digitais. A primeira delas tem a preocupação em compreender o impacto do culto às celebridades no jornalismo do portal Globo.com. A análise de conteúdo é usada pelo referido estudo, confirmando-se como uma das metodologias mais exploradas nas pesquisas em jornalismo digital. Outra tese, que procura saber como as redes sociais impactam no noticiário local da rede de televisão $R B S$, utiliza também esse tipo de análise. Por meio do estudo de caso (YIN, 1994) do Zero Hora, uma das pesquisas procura comprovar como os efeitos do algoritmo do Facebook podem transformar o conceito de newsmaking.

Em dois estudos, vê-se os preceitos da etnografia como opção metodológica. Em um deles, o pesquisador, que investiga o ethos e as crenças de um grupo de profissionais brasileiros dedicados ao Jornalismo Guiado por Dados, passa 60 horas acompanhando a equipe na redação do Estadão Dados, uma editoria do jornal O Estado de S. Paulo. Entrevistas em profundidade completam o levantamento de informações. No outro caso, a pesquisadora acompanha a redação de um programa de TV - Jornal da Globo -, também realiza entrevistas com os profissionais da área que investiga, bem como completa o levantamento de dados com a análise do telejornal. Entrevistas semiestruturadas compõem a metodologia do estudo de jornais populares. Nesse caso, a autora observa a estrutura de jornais populares na web - escolhe os jornais Extra, do Rio de Janeiro, e Diário Gaúcho, do Rio Grande do Sul -, bem como as interações dos leitores com os jornalistas.

O Pensamento Complexo, de Edgar Morin (2003) e a Sociologia Compreensiva, de Michel Maffesoli (1988) inspiram pesquisadores a aplicarem métodos de reflexão teóricometodológica no desenvolvimento de duas das teses analisadas. No primeiro caso, observa o entrelaçamento de sistemas abertos e fechados de mídia, mapeando posturas, condutas, costumes, decisões, rotinas e culturas da ambiência midiática. No segundo caso, a autora busca compreender teoricamente a concepção do jornalismo on-line e, então, a partir da etnografia, faz visitas presenciais à redação do portal ClicRBS, e netnografia, acompanhamento do portal ClicRBS - via web. Outra pesquisa também emprega a análise de conteúdo para observar os critérios de noticiabilidade no jornalismo em rede, a partir de publicações no Twitter de dez 
agências de notícias. E, ainda, uma das pesquisas adota o modelo de pesquisa híbrida, do Grupo de Pesquisa em Jornalismo On-line, do Programa de Pós-Graduação em Comunicação e Cultura Contemporâneas da Universidade Federal da Bahia, coordenado por Marcos Palacios e Suzana Barbosa. A proposta "incentiva a pesquisa qualitativa, incorpora os estudos de casos específicos como campos de prova para as hipóteses de trabalho" (MACHADO; PALACIOS, 2006, p. 199).

Quadro 1 - Teses da Pontifícia Universidade Católica do Rio Grande do Sul (PUC-RS)

\begin{tabular}{|c|c|c|c|c|c|}
\hline ANO & TÍTULO & AUTOR & ORIENTADOR & LINHA & MATRIZ EPISTEMOLÓGICA \\
\hline 2018 & $\begin{array}{l}\text { O culto às } \\
\text { celebridades nas } \\
\text { redes sociais e sua } \\
\text { influência no } \\
\text { conteúdo das notícias } \\
\text { no jornalismo on-line } \\
\text { do portal globo.com } \\
\text { Autora: Letícia } \\
\text { Amaral Carlan }\end{array}$ & $\begin{array}{l}\text { Letícia } \\
\text { Amaral } \\
\text { Carlan }\end{array}$ & Juliana Tonin & 1 & $\begin{array}{l}\text { O culto às celebridades nas redes } \\
\text { sociais é observado por meio da } \\
\text { análise de conteúdo para verificar } \\
\text { como esse fenômeno influencia o } \\
\text { jornalismo do portal globo.com. } \\
\text { Entre os eixos teóricos da tese, estão } \\
\text { newsmaking, noticiabilidade e } \\
\text { valor/notícia. }\end{array}$ \\
\hline 2018 & $\begin{array}{l}\text { A reconfiguração da } \\
\text { notícia: um estudo } \\
\text { sobre o impacto do } \\
\text { ciberacontecimento } \\
\text { na rotina produtiva } \\
\text { no telejornalismo }\end{array}$ & $\begin{array}{l}\text { Leandro } \\
\text { Olegario } \\
\text { dos } \\
\text { Santos }\end{array}$ & $\begin{array}{l}\text { Cristiane Finger } \\
\text { Costa }\end{array}$ & 2 & $\begin{array}{l}\text { Estuda os critérios de noticiabilidade } \\
\text { do Jornal do Almoço, da RBS, a } \\
\text { partir das redes sociais. Faz uso de } \\
\text { análise de conteúdo, com } \\
\text { aproximações à etnometodologia. As } \\
\text { matrizes teóricas são o telejornalismo } \\
\text { em contexto de convergência e o } \\
\text { valor notícia. }\end{array}$ \\
\hline 2017 & $\begin{array}{l}\text { É o algoritmo, } \\
\text { estúpido: como os } \\
\text { softwares provocam } \\
\text { alterações no } \\
\text { conceito de } \\
\text { newsmaking }\end{array}$ & $\begin{array}{l}\text { Paulo } \\
\text { Pinheiro } \\
\text { Gomes } \\
\text { Jr }\end{array}$ & $\begin{array}{l}\text { Eduardo } \\
\text { Campos } \\
\text { Pellanda }\end{array}$ & 1 & $\begin{array}{l}\text { Defende o surgimento de uma nova } \\
\text { categoria de newsmaking por causa } \\
\text { ação do algoritmo do Facebook. Para } \\
\text { tanto, fez uso do estudo de caso } \\
\text { (YIN, 1994) para analisar os efeitos } \\
\text { do algoritmo no jornal Zero Hora. O } \\
\text { conceito de newsmaking é revisitado } \\
\text { no ambiente digital. }\end{array}$ \\
\hline 2015 & $\begin{array}{l}\text { Para que servem os } \\
\text { comentários de } \\
\text { leitores na internet? } \\
\text { Estudo sobre a } \\
\text { utilidade da } \\
\text { ferramenta nos sites } \\
\text { de notícias a partir da } \\
\text { estrutura do } \\
\text { dispositivo e do } \\
\text { modo de apropriação } \\
\text { do internauta e do } \\
\text { veículo }\end{array}$ & $\begin{array}{l}\text { Thaisa } \\
\text { Cristina } \\
\text { Bueno }\end{array}$ & $\begin{array}{l}\text { Roberto } \\
\text { Tietzmann }\end{array}$ & 1 & $\begin{array}{l}\text { De caráter descritivo-analítico, } \\
\text { explora a Teoria do Meio e do } \\
\text { Interacionismo Simbólico. Faz uso do } \\
\text { mapeamento como ferramenta de } \\
\text { captação de dados, inspirada nos } \\
\text { critérios adotados pelo GJOL - } \\
\text { Grupo de pesquisa de jornalismo } \\
\text { online da UFBA. }\end{array}$ \\
\hline 2015 & $\begin{array}{l}\text { A reambientação do } \\
\text { jornalismo popular } \\
\text { no meio digital: uma } \\
\text { análise do Diário } \\
\text { Gaúcho e do Extra }\end{array}$ & $\begin{array}{l}\text { Karen } \\
\text { Sica Da } \\
\text { Cunha }\end{array}$ & $\begin{array}{l}\text { Eduardo } \\
\text { Campos } \\
\text { Pellanda }\end{array}$ & 1 & $\begin{array}{l}\text { Conceitos de convergência, consumo } \\
\text { e jornalismo popular são explorados. } \\
\text { De abordagem empírica e qualitativa, } \\
\text { adota múltiplos métodos e técnicas: } \\
\text { revisão bibliográfica, observação } \\
\text { sistemática e entrevistas } \\
\text { semiestruturadas. }\end{array}$ \\
\hline
\end{tabular}




\begin{tabular}{|c|c|c|c|c|c|}
\hline 2014 & $\begin{array}{l}\text { Entrevistando } \\
\text { planilhas: estudo das } \\
\text { crenças e do ethos de } \\
\text { um grupo de } \\
\text { profissionais de } \\
\text { jornalismo guiado } \\
\text { por dados no Brasil }\end{array}$ & $\begin{array}{l}\text { Marcelo } \\
\text { Ruschel } \\
\text { Träsel }\end{array}$ & $\begin{array}{l}\text { Francisco } \\
\text { Rüdiger }\end{array}$ & 1 & $\begin{array}{l}\text { Conceitos de ethos e de cibercultura } \\
\text { são discutidos para analisar } \\
\text { jornalistas que atuam com Jornalismo } \\
\text { Guiado por Dados. Como opção } \\
\text { metodológica, adota a observação da } \\
\text { redação Estadão Dados. }\end{array}$ \\
\hline 2014 & $\begin{array}{l}\text { As notícias e seus } \\
\text { critérios na } \\
\text { perspectiva da rede }\end{array}$ & $\begin{array}{l}\text { Gustavo } \\
\text { Buss } \\
\text { Cezar }\end{array}$ & $\begin{array}{l}\text { Mágda R. } \\
\text { Cunha }\end{array}$ & 1 & $\begin{array}{l}\text { Revisita conceitos de critérios de } \\
\text { noticiabilidade para compreender o } \\
\text { jornalismo em rede. A partir de } \\
\text { estudos de casos múltiplos (Twitter } \\
\text { de } 10 \text { agências de notícias), faz } \\
\text { observação sistemática e análise dos } \\
\text { critérios de noticiabilidade. }\end{array}$ \\
\hline 2010 & $\begin{array}{l}\text { Mídia fluida - um } \\
\text { estudo midiológico } \\
\text { aplicado na BBC }\end{array}$ & $\begin{array}{l}\text { Andréia } \\
\text { Denise } \\
\text { Mallma } \\
\text { nn }\end{array}$ & $\begin{array}{l}\text { Mágda R. } \\
\text { Cunha }\end{array}$ & 1 & $\begin{array}{l}\text { O Pensamento Complexo de Edgar } \\
\text { Morin é usado para compreender a } \\
\text { mídia contemporânea. Para tanto, } \\
\text { adota a auto-eco-organização para } \\
\text { mapear posturas, condutas, costumes, } \\
\text { decisões, rotinas e, por fim, culturas } \\
\text { dessa ambiência midiática. }\end{array}$ \\
\hline 2007 & $\begin{array}{l}\text { "Veja a seguir": a } \\
\text { transição do } \\
\text { telejornal entre a } \\
\text { linha de montagem e } \\
\text { a rede }\end{array}$ & $\begin{array}{l}\text { Fabiana } \\
\text { Piccinin }\end{array}$ & $\begin{array}{l}\text { Doris F. } \\
\text { Haussen }\end{array}$ & 2 & $\begin{array}{l}\text { Explora a teoria da economia política } \\
\text { da comunicação e o telejornalismo } \\
\text { em contexto de convergência para } \\
\text { compreender as mudanças } \\
\text { conjunturais e estruturais. Faz uso da } \\
\text { observação da redação do Jornal da } \\
\text { Globo, entrevista em profundidade e } \\
\text { análise do processo produtivo. }\end{array}$ \\
\hline 2007 & $\begin{array}{l}\text { Jornalismo em } \\
\text { tempos de } \\
\text { cibercultura: um } \\
\text { estudo do clicRBS }\end{array}$ & $\begin{array}{l}\text { Paula } \\
\text { Jung } \\
\text { Rocha }\end{array}$ & $\begin{array}{l}\text { Juremir } \\
\text { Machado da } \\
\text { Silva }\end{array}$ & 1 & $\begin{array}{l}\text { A evolução do jornalismo on-line é } \\
\text { observada a partir da construção } \\
\text { teórica-metodológica da tese, com } \\
\text { base na Sociologia Compreensiva } \\
\text { (Michel Maffesoli), etnografia e } \\
\text { netnografia do portal clicRBS. }\end{array}$ \\
\hline
\end{tabular}

Linha de Pesquisa 1 - Práticas Culturais nas Mídias, Comportamentos e Imaginários da Sociedade da Comunicação. Linha de Pesquisa 2 - Práticas Profissionais e Processos Sociopolíticos nas Mídias e na Comunicação das Organizações.

Fonte: As autoras, 2019.

No PPGCOM-Unisinos, seis teses pertencem à linha de pesquisa Midiatização e Processos Sociais, seis à Linguagem e Práticas Jornalísticas e um à Mídias e Processos Audiovisuais. As teses, destacadas no quadro 2, denotam a preocupação do único Programa nota 6 da região Sul em pensar o desenho teórico-metodológico de acordo com o objeto estudado. A professora do referido programa, Jiani Bonin, argumenta que "somente essa reflexão pode permitir e fecundar a reinvenção criadora, necessária para superar os limites e os obstáculos epistemológicos contidos nesses métodos e procedimentos de investigação" (BONIN, 2011, p. 37). Desse modo, os modelos prontos são descartados e a desconstrução metodológica de outras investigações sobre o mesmo tema é incentivada na pesquisa. 
As teses analisadas adotam múltiplos métodos e estão relacionadas às pesquisas do orientador. No caso dos trabalhos dirigidos por Antônio Fausto Neto, a concentração está nos estudos de midiatização - entendida "como um complexo conjunto de relações que se processam entre mídias, instituições e indivíduos, que se afetam mutuamente" (SGORLA,2015, p.13). Entre os autores que embasam as discussões sobre midiatização, estão o próprio Fausto Neto, José Luiz Braga, Stig Hjavard e Eliseo Verón ${ }^{4}$. São eles também que inspiram a construção teórico-metodológica para compreender como o ambiente midiático e seus públicos têm se transformado. Os objetos são variados: fan page do Jornal Nacional no Facebook, blogs esportivos e acontecimentos jornalísticos na web. Os estudos de casos são analisados a partir de práticas discursivas de diferentes instituições e indivíduos, adotando uma abordagem qualitativa.

Na mesma linha da Midiatização e Processos Sociais, há uma tese orientada por José Luiz Braga. Trata-se de um estudo sobre a circulação de saberes a respeito do jornalismo. A tese foi selecionada porque discute práticas jornalísticas na sociedade em midiatização e o ato da escrita ganha a dimensão de "método". Para José Luiz Braga, "na reflexão aforística ao reverso de fazer o texto para informar o conhecimento posto, rastreia-se o conhecimento pela escrita" (BRAGA, 2014, p. 18). Com um corpus amplo, são analisadas, a partir de um trabalho descritivo-inferencial dos casos selecionados, a circulação de práticas jornalísticas: fluxos na produção e apropriações de notícias, além da circulação da crítica jornalística entre especialistas e amadores.

$\mathrm{Na}$ linha de Linguagem e Práticas Jornalísticas, encontramos seis trabalhos, sendo que destes três são orientados por Ronaldo Henn, dois por Beatriz Marocco e um por Christa Berger. Três dos trabalhos dirigidos por Henn se orientam na semiótica para analisar o jornalismo em redes digitais. $\mathrm{Na}$ primeira tese, são realizadas ainda observações sistemáticas nas redações selecionadas (Folha de S. Paulo, New York Times e El País), além de entrevistas abertas para compreender o signo (notícia), seu objeto (acontecimento) e interpretante (jornalismo). Na segunda tese, os blogs fotojornalísticos são observados como outras narrativas possíveis na cultura digital. Além da inspiração etnográfica para a observação sistemática realizada no

\footnotetext{
4 Entre as obras mais citadas dos referidos autores, estão: 1) BRAGA, J. L. Lógicas da mídia, lógicas de midiatização? In: FAUSTO NETO et al. (org). Relatos de investigaciones sobre mediatizaciones. Rosário, UNR, 2015. Disponível em https://goo.gl/USqbuF. 2) VERÓN, E. Teoria da midiatização: uma perspectiva socioantropológica e algumas das suas consequências. Matrizes, v.8, n 1, 2014. 3) HJARVARD, S. A midiatização da cultura e da sociedade. São Leopoldo, Editora Unisinos, 2014.
} 
período de um ano, os editores dos dois blogs analisados (Focoblog - do Zero Hora e Diário da Foto - do Diário Gaúcho) são entrevistados. Os elementos das narrativas fotográficas são explorados e tensionados na análise dos dois blogs. A tese defendida mais recentemente e orientada por Henn apresenta uma proposta teórico-metodológica para compreender o ciberacontecimento breaknews inspirada no Teoria Ator Rede de Bruno Latour. O autor da tese entende a tecnologia como agente no fazer jornalístico e para defender essa perspectiva analisa três periódicos científicos internacionais (Journalism, Journalism Practice e Digital Journalism) que trataram do tema breaknews nos últimos dez anos.

As duas teses orientadas por Beatriz Marocco fazem uso de entrevistas como complemento metodológico para compreender as transformações do trabalho jornalístico. A primeira delas estuda, por meio da análise de discurso, os comentários blogs de fotorepórteres nos jornais O Globo, O Estado de S. Paulo, Zero Hora, Diário Gaúcho e Correio do Povo. A tese sobre agências nacionais de notícias do Brasil, Portugal e África explora ainda a observação participante, a pesquisa bibliográfica e documental, tensionando três operadores teóricos: jornalismo de agência, comunicação pública e estado.

Ainda na mesma linha de pesquisa, Christa Berger orienta uma tese sobre a prática do jornalismo em contexto de crise. A dialética e a práxis são usadas para pensar o passado, o presente e o futuro do jornalismo em três jornais: El País, Folha de S. Paulo e Zero Hora.

$\mathrm{Na}$ linha de pesquisa Mídia e Processos Audiovisuais, há uma única tese. Esta procura compreender o êxito do coletivo Nonada - Jornalismo de Travessia produzido em Porto Alegre, Rio Grande do Sul.

Quadro 2 - Teses da Universidade do Vale do Rio dos Sinos (Unisinos)

\begin{tabular}{|l|l|l|l|l|l|}
\hline ANO & TÍ́TUO & AUTOR & ORIENTADOR & LINHA & MATRIZ EPISTEMOLÓGICA \\
\hline 2018 & $\begin{array}{l}\text { Ciberacontecimen } \\
\text { to breaking news: } \\
\text { uma proposta } \\
\text { teórico- } \\
\text { metodológica para } \\
\text { a compreensão de } \\
\text { notícias urgentes } \\
\text { Cruz } \\
\text { Osório }\end{array}$ & Ronaldo Henn & 1 & $\begin{array}{l}\text { A proposta teórico-metodológica para o } \\
\text { ciberacontecimento breaking news está } \\
\text { embasada nos operadores Ator-Rede, } \\
\text { Rizoma e Cartografia Sentimental. Três } \\
\text { periódicos científicos (Journalism, } \\
\text { Journalism Practice e Digital } \\
\text { Journalism), de 2007 a 2016, são } \\
\text { analisados para buscar subsídios nos } \\
\text { estudos de break news. }\end{array}$ \\
\hline $\begin{array}{l}\text { Ética e } \text { worknet: a } \\
\text { conduta de si e o } \\
\text { trabalho de rede } \\
\text { na longevidade do } \\
\text { Nonada }-\end{array}$ & $\begin{array}{l}\text { Clarissa } \\
\text { Jornalismo } \\
\text { Travessia. }\end{array}$ & João Ladeira & 3 & $\begin{array}{l}\text { A partir da ética de Michel Foucault e } \\
\text { worknet de Bruno Latour, a autora } \\
\text { procura compreender a longevidade do } \\
\text { coletiva Nonada - Jornalismo de } \\
\text { Travessia. Entre os procedimentos } \\
\text { metodológicos adotados, está o } \\
\text { mapeamento de rastros digitais do }\end{array}$ \\
\hline
\end{tabular}




\begin{tabular}{|c|c|c|c|c|c|}
\hline & & & & & Nonada e de seus integrantes. \\
\hline 2018 & $\begin{array}{l}\text { Jornalismo de } \\
\text { Agência: a prática } \\
\text { de agências } \\
\text { nacionais nos } \\
\text { países lusófonos- } \\
\text { Brasil, Portugal, } \\
\text { Moçambique e } \\
\text { Angola. }\end{array}$ & $\begin{array}{l}\text { Juliana } \\
\text { Costa } \\
\text { Lisboa }\end{array}$ & Beatriz Marocco & 1 & $\begin{array}{l}\text { O jornalismo praticado em quatro } \\
\text { agências nacionais de notícias do Brasil, } \\
\text { Portugal e África, é descrito a partir da } \\
\text { observação participante nas redações nos } \\
\text { sites das agências, de entrevista com } \\
\text { profissionais e de pesquisa bibliográfica } \\
\text { e documental. Os eixos teóricos } \\
\text { explorados são jornalismo de agência, } \\
\text { comunicação pública e Estado. }\end{array}$ \\
\hline 2017 & $\begin{array}{l}\text { A práxis das } \\
\text { redações em } \\
\text { contexto de crise: } \\
\text { continuidades e } \\
\text { rupturas no } \\
\text { jornalismo }\end{array}$ & $\begin{array}{l}\text { Vanessa } \\
\text { Hauser }\end{array}$ & Christa Berger & 1 & $\begin{array}{l}\text { Os indícios de continuidade e rupturas } \\
\text { nas práticas e valores da profissão de } \\
\text { jornalista são analisados. Realiza } \\
\text { entrevistas semiestruturadas com onze } \\
\text { profissionais de três jornais de } \\
\text { referência: El País, Folha de S. Paulo e } \\
\text { Zero Hora. A dialética e a práxis são } \\
\text { usadas para pensar o passado, o presente } \\
\text { e o futuro do jornalismo. }\end{array}$ \\
\hline 2017 & $\begin{array}{l}\text { Heterotopias } \\
\text { fotojornalísticas: } \\
\text { os blogs de } \\
\text { fotografia dos } \\
\text { jornais impressos } \\
\text { de maior } \\
\text { circulação do } \\
\text { Brasil como } \\
\text { espaços de } \\
\text { produção e } \\
\text { reflexão dos } \\
\text { saberes e das } \\
\text { práticas } \\
\text { fotojornalísticas } \\
\text { na } \\
\text { contemporaneidad } \\
\text { e. }\end{array}$ & $\begin{array}{l}\text { Júlia } \\
\text { Capovill } \\
\text { a Luz } \\
\text { Ramos }\end{array}$ & Beatriz Marocco & 1 & $\begin{array}{l}\text { As práticas de fotorrepórteres nos blogs } \\
\text { de jornais O Globo, O Estado de S. } \\
\text { Paulo, Zero Hora, Diário Gaúcho e } \\
\text { Correio do Povo são analisadas a partir } \\
\text { de Michel Focault. Os blogs, que } \\
\text { despontam como espaço de comentários } \\
\text { jornalísticos, servem para compreender } \\
\text { as transformações da profissão. } \\
\text { Entrevistas e enquetes complementam a } \\
\text { metodologia que explora o discurso e a } \\
\text { produção dos fotojornalistas. }\end{array}$ \\
\hline 2016 & $\begin{array}{l}\text { A semiose da } \\
\text { notícia em } \\
\text { ambiente de crise: } \\
\text { movimentos em } \\
\text { rede e mediação } \\
\text { na semiosfera } \\
\text { contemporânea }\end{array}$ & $\begin{array}{l}\text { Felipe } \\
\text { Moura de } \\
\text { Oliveira }\end{array}$ & Ronaldo Henn & 1 & $\begin{array}{l}\text { Os conceitos de semiose (Peirce) e } \\
\text { semiosfera (Lotman) são usados para } \\
\text { compreender novas práticas do } \\
\text { jornalismo. A partir dos preceitos da } \\
\text { observação social sistemática, faz uma } \\
\text { imersão em três redações. A entrevista } \\
\text { aberta complementa o estudo. }\end{array}$ \\
\hline 2016 & $\begin{array}{l}\text { Complexificação } \\
\text { do acontecimento } \\
\text { na sociedade em } \\
\text { midiatização: } \\
\text { circulação e } \\
\text { atorização do caso } \\
\text { Gianecchini }\end{array}$ & $\begin{array}{l}\text { Elida de } \\
\text { Lima } \\
\text { Ferreira }\end{array}$ & Fausto Neto & 2 & $\begin{array}{l}\text { A partir do conceito de midiatização, } \\
\text { analisa estratégias discursivas por meio } \\
\text { de Análise de Discurso (AD). }\end{array}$ \\
\hline 2015 & $\begin{array}{l}\text { Complexificação } \\
\text { da zona de } \\
\text { contato na } \\
\text { ambiência } \\
\text { midiatizada: um }\end{array}$ & $\begin{array}{l}\text { Fabiane } \\
\text { Sgorla }\end{array}$ & Fausto Neto & 2 & $\begin{array}{l}\text { Explora os conceitos de midiatização e } \\
\text { zona de contato (Fausto Neto). É uma } \\
\text { abordagem qualitativa do estudo de caso. } \\
\text { O trabalho analítico tem como base a } \\
\text { sociossemiótica (Verón). }\end{array}$ \\
\hline
\end{tabular}




\begin{tabular}{|c|c|c|c|c|c|}
\hline & $\begin{array}{l}\text { estudo da } \\
\text { interação do } \\
\text { Jornal Nacional } \\
\text { com os receptores } \\
\text { na fan page no } \\
\text { Facebook }\end{array}$ & & & & \\
\hline 2015 & $\begin{array}{l}\text { Blogs } \\
\text { fotojornalísticos: } \\
\text { outras narrativas } \\
\text { possíveis na } \\
\text { cultura digital }\end{array}$ & $\begin{array}{l}\text { Beatriz } \\
\text { Sallet }\end{array}$ & Ronaldo Henn & 1 & $\begin{array}{l}\text { Charles Sanders Peirce orienta as } \\
\text { análises dos blogs. Os procedimentos } \\
\text { metodológicos adotados: entrevistas } \\
\text { semiestruturadas e netnografia. }\end{array}$ \\
\hline 2014 & $\begin{array}{l}\text { Midiatização do } \\
\text { jornalismo } \\
\text { esportivo em } \\
\text { ambiente digital: } \\
\text { interações entre } \\
\text { produtores e } \\
\text { receptores em } \\
\text { blogs dos } \\
\text { websites Espn- } \\
\text { Estadão, Sportv, } \\
\text { Placar e Lancenet }\end{array}$ & $\begin{array}{l}\text { Arnaldo } \\
\text { Oliveira } \\
\text { de Souza } \\
\text { Junior }\end{array}$ & Fausto Neto & 2 & $\begin{array}{l}\text { Explora conceitos de midiatização e } \\
\text { interações. A partir de estudo de caso } \\
\text { múltiplos, um protocolo é construído } \\
\text { para observação. Utiliza a análise do } \\
\text { discurso. }\end{array}$ \\
\hline 2014 & $\begin{array}{l}\text { Circulação de } \\
\text { saberes sobre } \\
\text { jornalismo na } \\
\text { sociedade em } \\
\text { midiatização } \\
\end{array}$ & $\begin{array}{l}\text { Caroline } \\
\text { Casali }\end{array}$ & José Luiz Braga & 2 & $\begin{array}{l}\text { Com base nos conceitos de midiatização } \\
\text { (Braga), observa casos múltiplos de } \\
\text { forma intencional. }\end{array}$ \\
\hline 2012 & $\begin{array}{l}\text { Embates sobre o } \\
\text { webjornalismo } \\
\text { brasileiro: } \\
\text { censura, controle } \\
\text { e resistência na } \\
\text { midiatização do } \\
\text { jornalismo na } \\
\text { internet }\end{array}$ & $\begin{array}{l}\text { Carmem } \\
\text { Lúcia } \\
\text { Souza da } \\
\text { Silva }\end{array}$ & Fausto Neto & 2 & $\begin{array}{l}\text { A partir de uma metodologia híbrida, } \\
\text { reflete sobre os conceitos de dispositivos, } \\
\text { midiatização, circulação, resistência e } \\
\text { poder. }\end{array}$ \\
\hline 2009 & $\begin{array}{l}\text { O jornalismo em } \\
\text { novos territórios } \\
\text { conceituais: } \\
\text { internet, } \\
\text { midiatização e a } \\
\text { reconfiguração } \\
\text { dos sentidos } \\
\text { midiáticos }\end{array}$ & $\begin{array}{l}\text { Demetrio } \\
\text { de } \\
\text { Azevedo } \\
\text { Soster }\end{array}$ & Fausto Neto & 2 & $\begin{array}{l}\text { Aprofunda os conceitos de midiatização, } \\
\text { território e novo território. Com base em } \\
\text { Verón, faz uso de estudo de casos. }\end{array}$ \\
\hline
\end{tabular}

Linha de Pesquisa 1 - Linguagem e Práticas Jornalísticas

Linha de Pesquisa 2 - Midiatização e Processos Sociais

Linha 3 - Mídias e Processos Audiovisuais

Fonte: As autoras, 2019.

No caso da UFRGS (ver quadro 3), das 11 teses que abordam o jornalismo digital quatro estão vinculadas à linha de pesquisa Informação, Redes Sociais e Tecnologias. Entre estes, três trabalhos são orientados por Alex Primo, com atenção para as interações em rede. Na tese Redes de comunicação pública, visibilidade e permanência do acontecimento público Tragédia Kiss, vinculada à linha de pesquisa Mediações e Representações Culturais e Políticas, orientada por 
Maria Helena Weber, o jornalismo digital não é o assunto principal, mas aparece como um dos componentes das redes de comunicação que permitem que o acontecimento tenha visibilidade e permanência na esfera pública. Neste caso, a investigação diferencia-se bastante em termos metodológicos, pois desenvolve uma pesquisa histórico-descritiva, com base na genealogia ${ }^{5}$, e a técnica de pesquisa documental, de onde resultou o acervo de dados que serviram à análise do funcionamento das redes.

Seis das teses de jornalismo digital da UFRGS estão na linha de pesquisa de Jornalismo e Processos Editoriais. Além da preocupação com a forma e o conteúdo, também se observa uma maior atenção com as audiências ativas. As metodologias adotadas são variadas, como pesquisa documental, análise de discurso e preceitos da netnografia. As abordagens teóricas se situam no âmbito dos contratos comunicativos, com base particularmente em Charaudeau, e estudos do ciberjornalismo articulados com newsmaking e teoria das redes. Há também uma proposta teórico-metodológica para analisar a construção do hipertexto em reportagens hipermídia, com base nas obras de George Landow.

A maioria das teses procura investigar modos e formas inovadoras do jornalismo digital adotados por jornais locais, nacionais e internacionais. Observamos neste conjunto de teses uma tendência de desenhos metodológicos complexos, que articulam métodos tradicionais, como análise de discurso ou análise de conteúdo, com o mapeamento de dinâmicas comunicativas, links, hashtags e uso de métricas, na tentativa de compreender não somente os novos fazeres jornalísticos, mas como as produções circulam e recirculam nas redes, gerando novos sentidos e apropriações.

Quadro 3 - Teses da Universidade Federal do Rio Grande do Sul (UFRGS)

\begin{tabular}{|l|l|l|l|l|l|}
\hline ANO & TíTULO & AUTOR & ORIENTADOR & LINHA & MATRIZ EPISTEMOLÓGICA \\
\hline 2018 & $\begin{array}{l}\text { Design de notícias } \\
\text { no cenário de } \\
\text { convergência } \\
\text { jornalística: práticas } \\
\text { profissionais em } \\
\text { jornais do Rio } \\
\text { Grande do Sul } \\
\text { Autor: }\end{array}$ & $\begin{array}{l}\text { Patrícia } \\
\text { Lopes } \\
\text { Damasceno }\end{array}$ & $\begin{array}{l}\text { Ana Claudia } \\
\text { Gruszynski }\end{array}$ & 3 & $\begin{array}{l}\text { O design de jornais é observado em } \\
\text { contexto de convergência por meio } \\
\text { de pesquisas bibliográficas, } \\
\text { documental e de entrevistas com 17 } \\
\text { profissionais dos jornais Zero Hora, } \\
\text { Correio do Povo, Pioneiro e Diário } \\
\text { de Santa Maria. }\end{array}$ \\
\hline
\end{tabular}

\footnotetext{
${ }^{5} \mathrm{O}$ método genealógico, criado por Nietzsche no fim do século XIX e desenvolvido posteriormente por Michel Foucault, é utilizado na pesquisa (FOUCAULT, 2014).
} 


\begin{tabular}{|c|c|c|c|c|c|}
\hline 2018 & $\begin{array}{l}\text { Jornalismo e } \\
\text { gênero: produção e } \\
\text { disputa de sentidos } \\
\text { no discurso dos } \\
\text { leitores }\end{array}$ & $\begin{array}{l}\text { Pâmela } \\
\text { Caroline } \\
\text { Stocker }\end{array}$ & $\begin{array}{l}\text { Marcia Benetti } \\
\text { Machado }\end{array}$ & 3 & $\begin{array}{l}\text { Os comentários dos leitores sobre } \\
\text { reportagens que abordaram a } \\
\text { transexualidade no Facebook da } \\
\text { revista Galileu, Folha de S. Paulo, } \\
\text { Globo Repórter e Fantástico. Faz } \\
\text { uso de pressupostos da Análise de } \\
\text { Discurso e da análise enunciativa } \\
\text { de Foucault. }\end{array}$ \\
\hline 2018 & $\begin{array}{l}\text { Jornal e } \\
\text { mobilidade: } \\
\text { reconfigurações do } \\
\text { impresso ao } \\
\text { multiplataforma }\end{array}$ & $\begin{array}{l}\text { Maíra de } \\
\text { Cássia } \\
\text { Evangelista } \\
\text { de Sousa }\end{array}$ & $\begin{array}{l}\text { Ana Claudia } \\
\text { Gruszynski }\end{array}$ & 3 & $\begin{array}{l}\text { Verifica como a mobilidade } \\
\text { transforma o jornal em suas } \\
\text { múltiplas plataformas em contexto } \\
\text { de convergência. De abordagem } \\
\text { qualitativa, o estudo adota a } \\
\text { pesquisa bibliográfica e documental } \\
\text { para analisar o jornal Zero Hora. }\end{array}$ \\
\hline 2017 & $\begin{array}{l}\text { Como contar } \\
\text { histórias? O } \\
\text { hipertexto } \\
\text { jornalístico na } \\
\text { reportagem } \\
\text { hipermídia }\end{array}$ & $\begin{array}{l}\text { Alciane } \\
\text { Nolibos } \\
\text { Baccin }\end{array}$ & $\begin{array}{l}\text { Luciana Pellin } \\
\text { Mielniczuk }\end{array}$ & 3 & $\begin{array}{l}\text { Com a intenção de compreender } \\
\text { como uma história é contada por } \\
\text { meio do hipertexto, a autora propõe } \\
\text { uma matriz metodológica para } \\
\text { analisar três reportagens multimídia } \\
\text { do The New York Times, do Público } \\
\text { e da Folha de S. Paulo. }\end{array}$ \\
\hline 2017 & $\begin{array}{l}\text { Jornalismo e } \\
\text { relevância: o } \\
\text { discurso dos } \\
\text { leitores dos jornais } \\
\text { de referência no } \\
\text { Facebook }\end{array}$ & $\begin{array}{l}\text { Silvana } \\
\text { Copetti } \\
\text { Dalmaso }\end{array}$ & $\begin{array}{l}\text { Marcia Benetti } \\
\text { Machado }\end{array}$ & 3 & $\begin{array}{l}\text { A relevância do jornalismo por } \\
\text { meio dos comentários no Facebook } \\
\text { dos jornais Estado de S. Paulo, } \\
\text { Folha de S. Paulo e O Globo. A } \\
\text { análise do discurso foi a } \\
\text { metodologia escolhida para } \\
\text { observar os comentários a partir de } \\
\text { três eixos teóricos: relevância, redes } \\
\text { sociais no jornalismo e o leitor. }\end{array}$ \\
\hline 2017 & $\begin{array}{l}\text { Os algoritmos do } \\
\text { Facebook: um } \\
\text { estudo dos } \\
\text { primeiros } 10 \text { anos } \\
\text { do feed de notícias }\end{array}$ & $\begin{array}{l}\text { Willian } \\
\text { Fernandes } \\
\text { Araújo }\end{array}$ & Alex Primo & 2 & $\begin{array}{l}\text { Ao acompanhar dez anos da } \\
\text { construção do feed de notícias do } \\
\text { Facebook ( } 2000 \text { a 2016), o autor } \\
\text { observa o avanço do uso do } \\
\text { algoritmo a partir da perspectiva de } \\
\text { estudos da ciência e tecnologia e da } \\
\text { Teoria Ator-Rede. Os textos } \\
\text { analisados são compreendidos } \\
\text { como dispositivos. }\end{array}$ \\
\hline 2016 & $\begin{array}{l}\text { Redes de } \\
\text { comunicação } \\
\text { pública, visibilidade } \\
\text { e permanência do } \\
\text { acontecimento } \\
\text { público Tragédia } \\
\text { Kiss (Santa Maria, } \\
\text { Brasil, 2013) } \\
\end{array}$ & $\begin{array}{l}\text { Bruno } \\
\text { Kegler }\end{array}$ & $\begin{array}{l}\text { Maria Helena } \\
\text { Weber }\end{array}$ & 1 & $\begin{array}{l}\text { As redes de comunicação pública } \\
\text { são tensionadas com o } \\
\text { acontecimento no jornalismo. A } \\
\text { pesquisa histórico-descritiva é } \\
\text { desenvolvida a partir do método } \\
\text { genealógico e de pesquisa } \\
\text { documental. }\end{array}$ \\
\hline 2014 & $\begin{array}{l}\text { Circulação e } \\
\text { recirculação de } \\
\text { narrativas do } \\
\text { acontecimento no } \\
\text { jornalismo em rede: } \\
\text { a Copa do Mundo } \\
\text { de } 2014 \text { no Twitter }\end{array}$ & $\begin{array}{l}\text { Gabriela da } \\
\text { Silva Zago }\end{array}$ & Alex Primo & 2 & $\begin{array}{l}\text { Analisa a circulação e a } \\
\text { recirculação jornalística em sites de } \\
\text { rede social e o acontecimento } \\
\text { jornalístico a partir do estudo de } \\
\text { caso. Com abordagem quantitativa } \\
\text { e qualitativa, faz uso da observação } \\
\text { sistemática e da Análise das Redes } \\
\text { Sociais (ARS) para compreender as } \\
\text { narrativas do Twitter. }\end{array}$ \\
\hline
\end{tabular}




\begin{tabular}{|c|c|c|c|c|c|}
\hline 2014 & $\begin{array}{l}\text { O jornal Zero Hora } \\
\text { e seus leitores no } \\
\text { contexto de } \\
\text { convergência } \\
\text { jornalística }\end{array}$ & $\begin{array}{l}\text { Cristiane } \\
\text { Lindemann }\end{array}$ & $\begin{array}{l}\text { Ana Claudia } \\
\text { Gruszynsky }\end{array}$ & 3 & $\begin{array}{l}\text { Estudos de newsmaking e de } \\
\text { convergência são revistados para } \\
\text { analisar as transformações do } \\
\text { espaço do leitor. Utiliza múltiplos } \\
\text { métodos: pesquisa documental, } \\
\text { entrevistas, observação participante } \\
\text { e análise de conteúdo. }\end{array}$ \\
\hline 2012 & $\begin{array}{l}\text { Jornalismo em } \\
\text { tempos de } \\
\text { convergência: } \\
\text { implicações da } \\
\text { distribuição } \\
\text { multiplataforma na } \\
\text { ampliação dos } \\
\text { contratos de } \\
\text { comunicação dos } \\
\text { dispositivos de Zero } \\
\text { Hora }\end{array}$ & $\begin{array}{l}\text { Vivian } \\
\text { Belochio }\end{array}$ & Alex Primo & 2 & $\begin{array}{l}\text { A partir do contrato de } \\
\text { comunicação de Charaudeau (2007) } \\
\text { analisa a produção multiplaforma. } \\
\text { De abordagem qualitativa, utiliza os } \\
\text { princípios da análise de discurso } \\
\text { para investigar as interações com o } \\
\text { público. }\end{array}$ \\
\hline 2011 & $\begin{array}{l}\text { Jornalismo líquido: } \\
\text { mediação } \\
\text { multinível e } \\
\text { notícias em fluxos }\end{array}$ & $\begin{array}{l}\text { Anelise } \\
\text { Rublescki }\end{array}$ & $\begin{array}{l}\text { Alexandre R. } \\
\text { da Silva }\end{array}$ & 2 & $\begin{array}{l}\text { Investiga metamorfoses do } \\
\text { jornalismo, em um momento em } \\
\text { que leitor e fontes tornam-se } \\
\text { instâncias coprodutoras de } \\
\text { conteúdo noticioso, a partir de } \\
\text { Mark Deuze e o contrato de } \\
\text { comunicação de Charaudeau. } \\
\text { Desenvolve estudos de casos de } \\
\text { ilustração, conforme metodologia } \\
\text { do GJOL/UFBA. }\end{array}$ \\
\hline
\end{tabular}

Linha de Pesquisa 1 - Mediações e Representações Culturais e Políticas

Linha de Pesquisa 2 - Informação, Redes e Tecnologias

Linha de Pesquisa 3 - Jornalismo e Processos Editoriais

Fonte: As autoras, 2019.

Na Universidade Tuiuti do Paraná (ver quadro 4), as quatro teses relacionadas ao tema do jornalismo digital estão vinculadas à linha de pesquisa Processos Mediáticos e Práticas Comunicacionais. A primeira delas se refere ao hiperconsumo de notícias, baseando-se em parte nos estudos do newsmaking para observar a valorização exacerbada da velocidade na produção jornalística on-line, buscando, por outro lado, analisar criticamente sob a perspectiva dos estudos sobre políticas de comunicação. A segunda tese analisa a nova estruturação do ethos do jornalista a partir da sua atuação multiplataforma desintermediada, quando se insere nas plataformas de interação on-line como o Twitter. Para isso, utiliza a Teoria Semiolinguística do Discurso e o conceito de contratos comunicativos. A terceira pesquisa estuda o webdocumentário interativo para observar novas práticas de produção, distribuição e consumo de produtos audiovisuais. Com base nas discussões teóricas sobre documentários audiovisuais, articuladas com estudos sobre internet e cibercultura, o autor desenvolveu fichas de análise comparativa e, por fim, uma ficha de mapeamento do ciclo interativo, para observar os elementos multimidiáticos, a interface e seus elementos gráficos, os padrões de navegação, a forma como os conteúdos foram 
organizados em camadas, os modos de interação ao longo das narrativas e aspectos de inovação e de reprodução dos formatos clássicos de documentário. Entrevistas com produtores de webdocumentário também fazem parte dos procedimentos metodológicos adotados. Na quarta tese, a autora estuda os recursos imersivos aplicados no contexto do jornalismo digital, que se propõem a ampliar o campo de visão do público em relação aos fatos noticiados pela mídia, por meio de uma linguagem sincrética, multimidiática e interativa. Trata-se de pesquisa engajada na confluência dos estudos de webjornalismo e de estratégias discursivas, enunciativas e tecnoestéticas de exploração das potencialidades tecnológicas, a partir de análise de conteúdo do objeto de estudo da reportagem The Displaced, primeira narrativa jornalística em realidade virtual publicada pelo jornal norte-americano The New York Times, que conta a história de três crianças, expulsas de suas casas pela guerra.

Quadro 4 - Teses da Universidade Tuiuti do Paraná

\begin{tabular}{|c|c|c|c|c|c|}
\hline ANO & TÍTULO & AUTOR & ORIENTADOR & LINHA & MATRIZ EPISTEMOLÓGICA \\
\hline 2018 & $\begin{array}{l}\text { A imersão no jornalismo } \\
\text { digital: recursos } \\
\text { discursivos, enunciativos } \\
\text { e tecnoestéticos da } \\
\text { reportagem The } \\
\text { Displaced, } \\
\text { disponibilizada no } \\
\text { aplicativo NYT VR }\end{array}$ & $\begin{array}{l}\text { Fernanda } \\
\text { Carraro } \\
\text { Dal-Vitt }\end{array}$ & Kati Caetano & 1 & $\begin{array}{l}\text { Pesquisa engajada na confluência } \\
\text { dos estudos de webjornalismo e } \\
\text { de estratégias discursivas, } \\
\text { enunciativas e tecnoestéticas de } \\
\text { exploração das potencialidades } \\
\text { tecnológicas. Emprega análise de } \\
\text { conteúdo da reportagem The } \\
\text { Displaced, do jornal norte- } \\
\text { americano The New York Times }\end{array}$ \\
\hline 2016 & $\begin{array}{l}\text { União e ruptura: estudo } \\
\text { das lógicas de criação, } \\
\text { produção e exibição do } \\
\text { webdocumentário } \\
\text { interativo (WDI) }\end{array}$ & $\begin{array}{l}\text { Alexandre } \\
\text { Torresani } \\
\text { de Lara }\end{array}$ & $\begin{array}{l}\text { Álvaro } \\
\text { Laranjeira }\end{array}$ & 1 & $\begin{array}{l}\text { Trata das reflexões sobre o } \\
\text { documentário audiovisual para } \\
\text { analisar as características e } \\
\text { potencialidades de } \\
\text { webdocumentários interativos, } \\
\text { partindo das teorias do } \\
\text { documentário e da cibercultura. }\end{array}$ \\
\hline 2015 & $\begin{array}{l}\text { Jornalismo de } \\
\text { hiperconsumo nos } \\
\text { principais portais do } \\
\text { Brasil }\end{array}$ & $\begin{array}{l}\text { Helton } \\
\text { Costa }\end{array}$ & $\begin{array}{l}\text { Álvaro } \\
\text { Laranjeira }\end{array}$ & 1 & $\begin{array}{l}\text { Articula discussões do } \\
\text { newsmaking (valores-notícia) e } \\
\text { jornalismo digital, com uma } \\
\text { crítica ao hiperconsumo e } \\
\text { políticas de comunicação, para } \\
\text { analisar os principais valores- } \\
\text { notícia presentes nas publicações } \\
\text { on-line. }\end{array}$ \\
\hline 2014 & $\begin{array}{l}\text { Presença on-line: } \\
\text { estratégias e práticas } \\
\text { discursivas na relação }\end{array}$ & $\begin{array}{l}\text { Lucina } \\
\text { Reitenbach } \\
\text { Viana }\end{array}$ & Kati Caetano & 1 & $\begin{array}{l}\text { Parte da Teoria Semiolinguística } \\
\text { do Discurso e o Contrato } \\
\text { Comunicacional para discussão }\end{array}$ \\
\hline
\end{tabular}




\begin{tabular}{|l|l|l|l|l|}
\hline $\begin{array}{l}\text { desintermidiada entre } \\
\text { coenunciadores no } \\
\text { Twitter }\end{array}$ & & & $\begin{array}{l}\text { do ethos jornalístico no atual } \\
\text { cenário midiático, apontando para } \\
\text { novas possibilidades de atuação } \\
\text { do jornalista. }\end{array}$ \\
\hline
\end{tabular}

Linha de Pesquisa 1 - Processos Mediáticos e Práticas Comunicacionais

Fonte: As autoras, 2019.

Da Universidade Federal de Santa Maria, três teses foram identificadas como pesquisa em jornalismo digital, como pode ser constatado no Quadro 5. Todas com orientação de Eugenia Maria Barichello, na linha de pesquisa Mídia e Estratégias Comunicacionais. Em uma delas, defendida em 2015, a pesquisadora empregou método qualitativo, incluindo observação exploratória nas páginas (fanpages) mantidas por quatro organizações jornalísticas brasileiras no Facebook: Estado de S. Paulo, O Globo, Folha de S.Paulo e Zero Hora; seleção e categorização de publicações de dois períodos (com um ano de diferença entre eles) e aplicação de protocolo de análise semiolinguística do material coletado. Utiliza pressupostos teóricos de midiatização e discute ecossistemas midiáticos (CANAVILHAS, 2011). A partir da teoria semiolinguística de Patrick Charaudeau (2013), busca compreender como as quatro organizações jornalísticas desenvolvem, nas publicações de suas páginas no Facebook, o contrato comunicativo com o qual se vinculam à audiência, e por meio de que estratégias semiolinguísticas o fazem.

Em 2016, uma tese abordou jornalismo digital, embora o foco principal tenha sido a comunicação organizacional. O autor observou como são firmados contratos de comunicação entre campos organizacional, midiático e político. Para analisar tais contratos, o corpus foi composto pelo blog Fatos e Dados, da Petrobras, o Blog do Noblat, do jornal O Globo, e o blog do Planalto da Presidência da República, entre os meses de janeiro a dezembro de 2015. Emprega triangulação de métodos e técnicas de pesquisa, envolvendo estudo de caso, pesquisa bibliográfica, observação encoberta não-participativa (JOHNSON, 2010), entrevista em profundidade e análise do contrato de comunicação (CHARAUDEAU, 2013).

A outra tese, defendida em 2018, teve como objetivo delinear o estatuto da autoria jornalística na ecologia da mídia, em suas dimensões epistemológica, deontológica e fenomenológica. $\mathrm{O}$ autor procurou analisar o webjornalismo regional no portal de notícias Ijui.com. Para tanto, aplicou métodos como observação (verificação in loco de rotinas produtivas), entrevistas em profundidade com equipe do portal e análise crítica do discurso, na perspectiva de Foucault e Bakhtin. Complementou a análise com dados obtidos nas versões online dos jornais Zero Hora e Folha de S.Paulo. 
Quadro 5 - Teses da Universidade Federal de Santa Maria (UFSM)

\begin{tabular}{|c|c|c|c|c|c|}
\hline ANO & TÍTULO & AUTOR & ORIENTADOR & LINHA & MATRIZ EPISTEMOLÓGICA \\
\hline 2018 & $\begin{array}{l}\text { De Gutenberg ao } \\
\text { jornalismo pós- } \\
\text { industrial: o percurso } \\
\text { do autor no } \\
\text { webjornalismo do } \\
\text { interior }\end{array}$ & $\begin{array}{l}\text { Marcio } \\
\text { da Silva } \\
\text { Granez }\end{array}$ & $\begin{array}{l}\text { Eugênia } \\
\text { Barichello }\end{array}$ & 1 & $\begin{array}{l}\text { De natureza fenomenológica, a } \\
\text { pesquisa investiga a autoria no } \\
\text { webjornalismo regional nas dimensões } \\
\text { epistemológica, deontológica e } \\
\text { fenomenológica. Trabalha com o } \\
\text { conceito de Ecologia Midiática, } \\
\text { analisando notícias no portal Ijui.com } \\
\text { traçando um paralelo com portais Zero } \\
\text { Hora e Folha de S.Paulo. }\end{array}$ \\
\hline 2016 & $\begin{array}{l}\text { Estratégias } \\
\text { comunicacionais no } \\
\text { contexto de crise: os } \\
\text { contratos de } \\
\text { comunicação da } \\
\text { Petrobras, O Globo e } \\
\text { Planalto em mídias } \\
\text { digitais }\end{array}$ & $\begin{array}{l}\text { Jones } \\
\text { Carvalho }\end{array}$ & $\begin{array}{l}\text { Eugênia } \\
\text { Barichello }\end{array}$ & 1 & $\begin{array}{l}\text { Procura analisar contratos de } \\
\text { comunicação por meio de um blog do } \\
\text { campo midiático, um do campo } \\
\text { político e um do campo organizacional. } \\
\text { Utiliza triangulação metodológica com } \\
\text { estudo de caso, pesquisa bibliográfica, } \\
\text { observação encoberta não-participativa, } \\
\text { análise de contrato de comunicação } \\
\text { (Charaudeau). }\end{array}$ \\
\hline 2015 & $\begin{array}{l}\text { Contrato de } \\
\text { informação do } \\
\text { Jornalismo no } \\
\text { ecossistema } \\
\text { midiatizado: } \\
\text { estratégias } \\
\text { semiolinguísticas da } \\
\text { instância de produção } \\
\text { do Facebook }\end{array}$ & $\begin{array}{l}\text { Luciana } \\
\text { Carvalho }\end{array}$ & $\begin{array}{l}\text { Eugênia } \\
\text { Barichello }\end{array}$ & 1 & $\begin{array}{l}\text { O contrato de comunicação } \\
\text { (Charaudeau) é acionado para } \\
\text { compreender as interações do } \\
\text { jornalismo em rede. Entre os } \\
\text { procedimentos metodológicos } \\
\text { adotados, faz uso da observação } \\
\text { exploratória (fanpages do Facebook } \\
\text { dos jornais Estado de S. Paulo, O } \\
\text { Globo, Folha de S.Paulo e Zero Hora) e } \\
\text { aplicação de protocolo de análise } \\
\text { semiolinguística do material coletado. }\end{array}$ \\
\hline
\end{tabular}

Linha de Pesquisa 1 - Mídia e Estratégias Comunicacionais

Fonte: As autoras, 2019.

Na Universidade Federal de Santa Catarina (ver quadro 6), duas teses foram analisadas no contexto de jornalismo digital para este artigo, uma em cada linha de pesquisa do Programa de Pós-Graduação em Jornalismo. Na primeira, defendida em 2017, com orientação de Raquel Longhi, o autor observa a priorização da produção de conteúdo informativo para plataformas digitais em redações com um fluxo de trabalho até então regrado pelo ritmo do impresso como um novo e necessário ciclo de inovação em empresas jornalísticas. Realiza entrevistas em profundidade com lideranças estratégicas de oito jornais, entre empresas do Brasil, da Argentina e da Espanha, buscando problematizar as mudanças vivenciadas no cenário atual e, também, aquelas projetadas para o futuro de curto e de médio prazo no que diz respeito às rotinas produtivas no jornalismo digital.

A segunda tese analisada, de 2018, foi orientada por Rogério Christofoletti. A autora procura observar métricas editorias e suas ações e associações no processo produtivo do jornalismo on-line. Promove reflexão teórico-metodológica sobre newsmaking com aproximação 
ao campo da antropologia por meio da Teoria Ator-Rede. Trata-se de pesquisa etnográfica que emprega pressupostos de Bruno Latour (2012) para observar as mediações, a simetrização, as controvérsias e as agências distribuídas em rede. Para tanto, foram realizadas incursões nas editorias de audiência on-line da British Broadcasting Corporation (BBC), do The Guardian (ambos em Londres, na Inglaterra) e da Folha de S. Paulo, em São Paulo, no Brasil, durante o ano de 2017.

Quadro 6 - Teses da Universidade Federal de Santa Catarina (UFSC)

\begin{tabular}{|c|c|c|c|c|c|}
\hline ANO & TÍTULO & AUTOR & ORIENTADOR & LINHA & MATRIZ EPISTEMOLÓGICA \\
\hline 2018 & $\begin{array}{l}\text { Métricas } \\
\text { editoriais no } \\
\text { jornalismo on- } \\
\text { line: ética e } \\
\text { cultura } \\
\text { profissional na } \\
\text { relação com } \\
\text { audiências } \\
\text { ativas }\end{array}$ & $\begin{array}{l}\text { Lívia de } \\
\text { Souza } \\
\text { Vieira }\end{array}$ & $\begin{array}{l}\text { Rogério } \\
\text { Christofoletti }\end{array}$ & 1 & $\begin{array}{l}\text { Reflexão teórico-metodológica } \\
\text { sobre o newsmaking com } \\
\text { aproximação ao campo da } \\
\text { antropologia por meio da Teoria } \\
\text { Ator-Rede. Pesquisa etnográfica } \\
\text { com pressupostos de Bruno } \\
\text { Latour (2012) na observação de } \\
\text { mediações, simetrização, } \\
\text { controvérsias e agências } \\
\text { distribuídas em rede. }\end{array}$ \\
\hline 2017 & $\begin{array}{l}\text { Inversão de } \\
\text { papel: } \\
\text { prioridade ao } \\
\text { digital como um } \\
\text { novo ciclo de } \\
\text { inovação para } \\
\text { jornais de } \\
\text { origem impressa }\end{array}$ & $\begin{array}{l}\text { Alexandre } \\
\text { Lenzi }\end{array}$ & Raquel Longhi & 2 & $\begin{array}{l}\text { Entrevistas em profundidade com } \\
\text { lideranças estratégicas de jornais } \\
\text { do Brasil, da Argentina e da } \\
\text { Espanha, problematizando } \\
\text { mudanças vivenciadas e } \\
\text { projetadas no que diz respeito às } \\
\text { rotinas produtivas no jornalismo } \\
\text { digital. }\end{array}$ \\
\hline
\end{tabular}

Linha de Pesquisa 1 - Jornalismo, Cultura e Sociedade

Linha de Pesquisa 2 - Tecnologias, Linguagens e Inovação no Jornalismo

Fonte: As autoras, 2019.

\section{CONSIDERAÇÕES}

A convergência de meios parece ter ampliado os estudos em jornalismo na internet, uma vez que a produção, a circulação e os fluxos interacionais também estão inseridos no ambiente digital. Na região Sul, primeira etapa da pesquisa sobre metodologias e práticas jornalísticas que inclui outras regiões do País, os estudos em jornalismo digital ainda são reduzidos quando consideramos a quantidade de teses defendidas. No período analisado (2006-2018), há 510 teses no conjunto dos Programas de Pós-graduação em Comunicação da Região Sul, destas apenas 43 pesquisam o jornalismo digital - o que representa 8,4 por cento do total.

Em estudo anterior (QUADROS et al, 2006, 2006) analisamos a produção científica de pioneiros brasileiros nos estudos em jornalismo digital (1995 a 2005), que fizeram uso de diferentes procedimentos metodológicos para compreender o estado da arte deste recorte 
temporal. ${ }^{6}$ No entanto, na época enfatizamos a necessidade de refletir de forma mais profunda sobre as questões metodológicas nas pesquisas em jornalismo digital. Por isso, neste artigo, acompanhamos a evolução desses estudos nos últimos doze anos (2006-2018). Inferimos que o conhecimento produzido até agora e as próprias transformações das práticas jornalísticas exigem uma construção metodológica mais complexa para compreender os fenômenos do jornalismo em redes digitais. Desde 2005, o impacto sobre a participação do público tem sido alvo de interesse de pesquisas deste campo. Agora, os leitores e as fontes adquirem protagonismos nas investigações sobre o jornalismo em contexto de convergência. Nos últimos três anos o interesse também se estende para os algoritmos. As pesquisas brasileiras dialogam com a referências internacionais quando observamos as preocupações ao longo do período abrangido, pois também encontramos nas pesquisas analisadas uma perspectiva mais sociológica (SALAVERRÍA, 2019) do jornalismo. Tal fato também está associado aos projetos realizados em parceria com outros países, como a Espanha, França, Portugal e Estados Unidos.

Os programas de pós-graduação da região Sul, reconhecidos pela tradição nos estudos de recepção (Unisinos, PUC-RS, UFRGS, UFSM e UFSC), certamente se beneficiam com essa experiência teórica-metodológica para analisar as interações da sociedade midiatizada. Teorias tradicionais, como o newsmaking, são revisitadas para compreender os movimentos do jornalismo em redes digitais. As metamorfoses do jornalismo também são tensionadas para pesquisar outras questões, como as redes de comunicação pública. E isso demonstra a importância dos estudos do jornalismo e de sua contribuição para o avanço da pesquisa na área.

O protagonismo do público nos estudos do jornalismo digital dos últimos doze anos (2006-2018), por outro lado, tem aumentado o interesse pela Teoria do Contrato de Comunicação estabelecido entre a mídia e seus leitores. Neste caso, devemos considerar ainda a influência de pesquisadores reconhecidos na área da comunicação sobre seus alunos e orientandos. Também encontramos estudos que adotam perspectivas multidisciplinares, como destacado anteriormente por Lago e Benetti (2010). Ao contrário do que as referidas autoras apontaram sobre a falta de rigor na descrição de métodos e técnicas das pesquisas em jornalismo, há uma maior preocupação nas teses de doutorado em apresentar detalhadamente o desenho

\footnotetext{
${ }^{6}$ Os resultados encontrados na referida pesquisa mostraram que a maior parte dos pioneiros tinha pós-graduação em jornalismo digital no exterior e, portanto, traziam em suas pesquisas metodologias mais utilizadas nos países em que estudaram: Estados Unidos, França, Espanha e Portugal. A maioria das pesquisas tinha um perfil mais qualitativo para abordar diferentes preocupações: resgate histórico do jornalismo digital, valorização da pesquisa aplicada, novos sistemas de produção e distribuição, rotinas e reconfigurações profissionais, negócios, ensino, tecnologia e, sobretudo, metodologias. Já havia uma preocupação em pensar metodologias diferentes para conseguir compreender as transformações que ocorriam no jornalismo digital.
} 
teórico metodológico e adaptá-lo para o objeto de estudo do jornalismo em contexto de convergência. E as metodologias adotadas, como detalhadas nos tópicos de cada programa de pós-graduação, são variadas. Métodos e técnicas considerados tradicionais, como Análise de Conteúdo e entrevistas, são muito explorados e, destaca-se, revisitados para ganhar o apoio dos preceitos da netnografía.

Inferimos que pelo prazo concedido pela Capes para a conclusão do doutorado (48 meses) ser mais longo que a do mestrado (24 meses), as reflexões sobre as novas práticas jornalísticas estão mais presentes nos trabalhos defendidos nos últimos três anos. Se as novas práticas jornalísticas estão associadas as recentes transformações incluídas no processo produtivo do jornalismo, tal como propõe Del Vecchio e Caetano (2015), ao término de quatro anos tempo máximo para a defesa de doutorado - as referidas práticas já não serão tão novas assim. No entanto, percebemos uma preocupação em compreender o objeto sob diferentes perspectivas. Dito de outro modo, as análises não refletem apenas sobre o conteúdo do jornalismo digital. Há interesse no jornalista, no processo produtivo, no conteúdo, nas interações com o público/produtor e na opinião gerada pelos comentários dos leitores.

Em relação ao período pesquisado anteriormente (1995-2005), nota-se na década posterior um amadurecimento na abordagem metodológica, que se expressa numa maior complexidade e combinação de múltiplos procedimentos de pesquisa. As investigações revisitam conceitos clássicos do jornalismo como newsmaking e critérios de noticiabilidade, agora aplicados a um novo ambiente e contexto. Ainda no foco da produção de notícias, técnicas etnográficas são aplicadas para compreender as rotinas produtivas e suas transformações. A análise de conteúdo e de discurso são algumas das metodologias mais exploradas nas pesquisas em jornalismo digital. No entanto, uma mudança significativa em relação ao período anterior se refere a um conjunto de pesquisas que tem trabalhado com o mapeamento de dinâmicas comunicativas e ciclos interativos. Links, hashtags e uso de métricas que buscam revelar novos modos de produção, circulação e apropriação dos conteúdos jornalísticos. Observam-se também aspectos multimidiáticos, interfaces e seus elementos gráficos, assim como os padrões de navegação e organização dos conteúdos em camadas que podem determinar inovações ao longo das narrativas.

Os resultados apresentados neste artigo revelam apenas características das teses defendidas na região Sul, que possui seis Programas de Pós-graduação com doutorado . Um panorama

\footnotetext{
${ }^{7}$ Três dos cursos de doutorado têm quase duas décadas de existência, mas os outros três são mais recentes. O da UFSC foi reconhecido em 2014, o da UFSM em 2012 e o da UTP em 2010, conforme mostra o quadro 1.
} 
completo das pesquisas em jornalismo digital só será possível com a análise das teses defendidas em outras regiões do país e com o cruzamento dos resultados alcançados em outros trabalhos desenvolvidos sobre o tema ${ }^{8}$ de docentes e discentes envolvidos neste esforço coletivo.

\section{REFERÊNCIAS}

BAKHTIN, M. Estética da criação verbal. São Paulo: Martins Fontes, 1992.

BAKHTIN, M. Questões de literatura e de estética: a teoria do romance. 3.ed. São Paulo: Hucitec, 1993.

BAKHTIN, M. Marxismo e filosofia da linguagem. 9.ed. São Paulo: Hucitec, 1995.

BONIN, J. Revisitando os bastidores da pesquisa: práticas metodológicas na construção de um projeto de investigação. In MALDONADO, A. E. (org). Metodologias de Pesquisa em Comunicação. Porto Alegre: Sulina, 2011.

BRAGA, J. L. Um conhecimento aforístico. In XXIII Encontro Anual da Compós, Belém/PA: UFPA, 2014.

CANAVILHAS, J. WebJornalismo: Considerações Gerais Sobre Jornalismo na Web. In I Congresso Ibérico de Comunicação. Covilhã, UBI, 1999.

CANAVILHAS, J. El nuevo ecosistema mediático. Index Comunicación, vol. 1, p. 13-24, 2011.

CHARAUDEAU, P. Discurso das mídias. São Paulo: Contexto, 2013.

DEL VECCHIO DE LIMA, M. R.; CAETANO, K. E. Implicações epistemológicas da pesquisa sobre novas práticas jornalísticas: por onde começar? Revista Famecos, Porto Alegre, v. 22, n. 3, 2015.

ELDRIDGE II, S. A; HESS, K.; TANDOC JR, E. Digital Journalism (Studies) - Defining the Field. Digital Journalism, v 7, número 3, 315-317, 2019.

ESCOSTEGUY, A. C. D. Comunicação e gênero: notas de um diário da docência e da pesquisa. In ESCOSTEguY, A. C. D. (org.). Comunicação e gênero: a aventura da pesquisa. Porto Alegre: PUCRS, 2008.

FERREIRA, N. S. A. As pesquisas denominadas “estados da arte". Educação \& Sociedade,v. 79, 2002. Disponível em https://goo.gl/HlmXV6. Acesso em 18 de julho de 2017.

FIEBIG, M. F. O território da cibercultura: cartografia da produção científica em periódicos brasileiros (2006-2015) e aberturas epistemológicas. Dissertação de mestrado defendida no Programa de Pós-graduação em Comunicação da Universidade Federal do Paraná. Curitiba, UFPR, 2017.

\footnotetext{
${ }^{8}$ Pesquisadores envolvidos no projeto de pesquisa "Novas práticas do jornalismo" já analisaram artigos científicos apresentados na SBPJor (DEL VECCHIO DE LIMA; CAETANO, 2015) e o jornalismo digital nas revistas de comunicação classificadas como qualis A2 (FIEBIG, 2017).
} 
FOUCAUlT, M. História da Sexualidade 1: A vontade de saber. Trad. Maria Thereza da Costa Albuquerque e J. A. Guilhon Albuquerque. São Paulo, Paz e Terra, 2014.

Fragoso, S.; ReCUero, R.; AMARAL, A..Métodos de Pesquisa para Internet. Porto Alegre: Sulina, 2015.

JOHNSON, T. Pesquisa social mediada por computador: questões, metodologia e técnicas qualitativas. Rio de Janeiro: E-papers, 2010.

LAGO, C.; BENETTI, M. Metodologia de Pesquisa em Jornalismo. Petrópolis: Vozes, 2010.

MACHADO, E. La estructura de la noticia en las redes digitales: un estudio de las consecuencias de las metamorfosis tecnológicas en el periodismo. (Tese de Doutorado). Universidad Autónoma de Barcelona, Barcelona, 2000.

MACHADO, E.; PALACIOS, M. Um modelo híbrido de pesquisa: a metodologia aplicada pelo GJOL. In LAGO, Claudia e BENETTI, Marcia. (Org.). Metodologia de pesquisa em jornalismo. Petrópolis: Vozes, 2007, pp. 199-222.

MAFFESOLI, M. O conhecimento comum. Compêndio de sociologia compreensiva. São Paulo: Brasiliense, 1988.

MIELNICZUK, L. Sistematizando alguns conhecimentos sobre jornalismo na web. In: PALACIOS, M.; MACHADO, E. (Org.). Modelos de jornalismo digital. Salvador: Calandra, 2003.

MORIN, E. Introdução ao pensamento complexo. 4ed. Lisboa: Instituto Piaget, 2003.

PRIMO, Alex (org.). Mapeamento 2: do ensino de jornalismo digital no Brasil em 2010. São Paulo: Itáu Cultural, 2010.

QUADROS, C. I.; MIELNICZUK, L.; BARBOSA, S. Os Estudos sobre o jornalismo digital no Brasil, ECompós, v 7, número 3, p. 1 - 22, 2006.

SALAVERRÍA, R. Digital journalism: 25 years of research. Review article. El profesional de la información, v. 28, n.1, 2019.

STEENSEN, S.; LARSEN, A. M. G.; HÅGVAR, Y. B.; FONN, B. K. What Does Digital Journalism Studies Look Like?, Digital Journalism, v 7, número 3, 320-3427, 2019.

YIN, R. K. Estudo de caso - planejamento e métodos. Porto Alegre: Bookman. 1994. 
Pós-doutora em Comunicação pela Universidade Pompeu Fabra e doutora em Comunicação pela Universidade de La Laguna. Professora do PPGCOM da UFPR.

Mônica Cristine Fort

Pós-doutora em Comunicação pela UERJ e doutora em Engenharia da Produção pela UFSC. Professora do PPGCOM-UTP.

Mônica Panis Kaseker

Doutora em Ciências Sociais pela Universidade Federal do Paraná. Professora do PPGCOM da UEL.

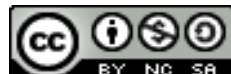

Esta obra está licenciada com uma Licença

Creative Commons Atribuição-NãoComercial-CompartilhaIgual 4.0 Internacional 


\section{Apêndice}

\section{FICHA DE LEVANTAMENTO DE TESES/DISSERTAÇÕES}

$1{ }^{\text {a }}$ FASE - ORGANIZAÇÃO DA BASE DE DADOS

\begin{tabular}{|l|}
\hline Título da tese: \\
\hline Nome do(a) autor(a): \\
\hline Nome do(a) orientador(a): \\
\hline Nome da instituição e região: \\
\hline Resumo: \\
\hline Palavra-chave: \\
\hline Data da defesa (dia/mês/ano): \\
\hline Tema: \\
\hline Link para acesso à tese: \\
\hline Responsável pela coleta: \\
\hline
\end{tabular}

\section{$2^{\text {a }}$ FASE - LEITURA E ANÁLISE PARA SISTEMATIZAÇÃO DOS DADOS}

1) A tese/dissertação tem como propósito investigar propostas criativas/inovadoras no jornalismo em redes digitais?

2) Qual tipo de abordagem teórico-metodológica foi adotada para o exame da práticas em foco, e quais os empíricos estudados (especificar detalhadamente)?

3) Quais são os principais autores destacados no trabalho (matrizes teóricas)?

4) Utiliza metodologia incorporada de outras pesquisas ou propõe uma metodologia própria para o objeto investigado? Descrever resumidamente a metodologia proposta em qualquer das respostas.

5) Que conclusões apresenta no tocante às práticas serem, de fato, inovadoras ou não, e, em caso afirmativo, em que aspecto as inovações se apresentam?

\section{Responsável pela coleta:}

